\title{
Pola Konflik Keagamaan dan Analisa Peran Stakeholder (Kajian Multisitus di Kabupaten Jember dan Kabupaten Bondowoso)
}

\author{
Abd. Halim Soebahar \\ Fakultas Tarbiyah dan Ilmu Keguruan IAIN Jember \\ E-mail: ahalims1961@gmail.com \\ Abdul Karim \\ Fakultas Tarbiyah dan Ilmu Keguruan IAIN Jember \\ E-mail: karimaldanief@gmail.com
}

\begin{abstract}
Abstrak: Konflik keagamaan yang sering terjadi di Indonesia banyak disebabakn oleh perbedaan dalam mehami sumber hukum islam yakni al-Qur'an. Penilitian ini mencoba ingin mengungkap berbagai permasalah yang terjadi dalam perselisihan keagamaan di Kabupaten Jember dan Bondowoso. Hasil Penelitian ini menunjukan: 1) Pola Perselisihan Paham keagamaan di wilayah Kabupaten Jember dan Kabupaten Bondowoso diantaranya, yaitu: a) Pola perselisihan paham keagamaan berskala lokal, Nasional dan Internasional. b) Pola keyakinan dan tafsirnya yang kontroversi terhadap teks keagamaan. c) Pelibatan tokoh dengan otoritasnya menyebabkan perselisihan kegamaan ditingkat dearah. d) Model tausiyah kegamaan yang kontroversial dan ujuran kebencian. 2) Peran institusi keagamaan MUI, FKUB dan Kementerian Agama dalam menangani perselisihan paham keagamaan di wilayah Kabupaten Jember dan Kabupaten Bondowoso, yaitu: a) Memberi kepastian hukum terhadap ajaran kelompok yang menyimpang dengan fatwa-fatwa yang mencerahkan. b) Organisasi keagamaan melakukan proteksi dini. c) Pembinaan-pembinaan hubungan umat beragama melalui instansi pemerintah dan lembaga swasta. 3) Solusi perselisihan paham keagamaan di wilayah Kabupaten Jember dan Kabupaten Bondowoso diantaranya, yaitu: a) Pemerintah berkawajiban untuk menindak tegas dan melarang aktivitas aliran yang dianggap menyimpang. b) Pro aktif masyarakat untuk mengawasi setiap gerak gerik penyebaran ajaran yang disebarkan oleh eks kelompok menyimpang. c) Paham-paham keagamaan bersikap inklusif dan moderat terhadap kelompok lain. d) Strategi dakwah yang berhaluan dakwah rahmatan lil alamin. e) Pembinaan secara continue pasca konflik. f) Membentuk desa siaga konflik. g) Terbentuknya Tim terpadu dari organisasi pemerintah dan non pemerintah.
\end{abstract}

Kata Kunci: Perselisihan, Paham Keagamaan, Institusi Keagamaan

Abstract: Religious conflicts that often occur in Indonesia are caused by dissenting points of view in understanding the source of Islamic law, namely the al-Qur'an. This study tries to know religious disputes in Jember and Bondowoso Regencies. The results of this study show that: 1) The pattern of disputes over religious understanding in the Jember and Bondowoso regencies includes: a) The pattern of disputes over religious understanding on a local, national and international scale. b) Pattern of controversial beliefs and interpretations of religious texts. c) The involvement of figures with their authority causes religious disputes at the regional level. d) The controversial religious religious sermon littered fully with hate speech. 2) The roles of religious institutions such as MUI, 
FKUB and the Ministry of Religious Affairs in handling disputes over religious understanding in Jember and Bondowoso regencies, namely: a) Providing legal certainty for deviant group teachings with enlightening fatwas. b) Religious organizations carrying out early protection. c) Fostering religious relations through government agencies and private institutions. 3) The solutions to disputes over religious understanding in the Jember and Bondowoso regencies include: a) The government is obliged to take a firm stand and prohibit activities of religious groups that are considered deviant. b) Pro-active society to take account of any activities in spreading teachings conducted by deviant groups. c) Religious ideas are inclusive and moderate towards other groups. d) Preaching strategies which are oriented towards the so-called rahmatan lil alamin. e) Giving continuous guidance after the conflict. f) Forming conflict alert villages. g) The establishment of an integrated team from both government and non-government organizations.

Keywords: Disputes; Religious Understanding; Religious Institutions

\section{Pendahuluan}

Kebebasan, khususnya dalam kehidupan beragama dan bermasyarakat, yang terjadi pada era reformasi telah melahirkan banyak peluang dan sekaligus tantangan. Di satu sisi aktivitas dakwah dan organisasi berjalan dengan lancar dan berbagai nilai Islam yang mendasar dengan leluasa disuarakan tanpa hambatan yang berarti. Tapi, di sisi lain, dengan kebebasan itu pula aliran atau kelompok yang menyuarakan pemikiran, paham dan aktivitas yang bertentangan juga dengan leluasa bergerak dan berkembang di tengah masyarakat.

Secara umum agama menjadi sumber pokok nilai yang ada dalam kebudayaan. Namun demikian, nilai-nilai tersebut tidak bisa dengan sendirinya mewujud dalam praktek hidup manusia. Dengan kata lain, nilai, gagasan, spirit yang diperkenalkan agama, termasuk Islam didalamya, masih bersifat pasif. Tentunya, operasionalisasinya menjadi tugas berat para pemeluknya. Di sinilah salah satu letak masalahnya. Sejauh mana agama bisa membantu proses internalisasi nilai dimaksud tersebut. Pada poin ini, seperti pandangan Soedjatmoko, harus dibedakan antara kekayaan khasanah, pikiran, dan kaidah-kaidah agama yang ada dalam kitab suci, atau buku agama, dengan kemampuan pemeluknya atau lembaganya untuk memegang peran peradaban, atau pengendali sejarah. ${ }^{1}$

Berbagai persoalan terkait kehidupan intra dan antar umat beragama, mulai dari ekspresi keagamaan sampai pada pendirian rumah ibadah, mungkin bukan lagi hal baru atau bahkan sudah dianggap usang. Bisa jadi karena berbagai persoalan yang muncul selalu dianggap sebagai bagian dari bungkus (kedok) atas persoalan ekonomi ataupun politik. Tapi diakui atau tidak, persoalan ini seolah tidak pernah ditemukan ujung pangkal penyelesaiannya. Meski berbagai cara telah dilakukan, mulai dari penyuluhan, pembinaan, sampai pada dibuatnya berbagai aturan dan kebijakan, namun berbagai persoalan serupa seolah terus muncul. Kapan saja dan di mana saja. Bahkan dalam skala tertentu bisa menjadi ancaman bagi keutuhan kehidupan berbangsa dan bernegara.

Imam Tholkhah dan Abdul Aziz mengemukakan konsep deprivasi. Deprivasi, merupakan cikal bakal lahirnya suatu gerakan sosial baru. Menurut keduanya, bahwa konsep

\footnotetext{
${ }^{1}$ Soedjatmoko. Agama dan Hari Depan Umat Manusia, dalam Effendi Islam dan Dialog Budaya (Jakarta: Puspa Swara, 1994), 79.
} 
deprivasi Glock dan Stark sangat relevan dengan munculnya berbagai gerakan keagamaan di Indonesia, terutama berkenaan dengan kasus-kasius keagamaan di Indonesia meskipun bukan satu-satunya motivator bagi tumbuhkembangnya aliran keagamaan baru. Kelahiran suatu aliran keagamaan baru diilhami oleh tradisi kebebasan dalam memahami agama yang diajarkan oleh Al-Qur'an. ${ }^{2}$

Dalam konteks negara Indonesia, perselisishan keagamaan sering muncul dari akibat perbedaan pemahaman tafsir wahyu Al-Qur'an, sehingga perbedaan ini tidak jarang malahirkan perselisihan dan tindak kekerasaan di intra umat beragama, khsusnya agama islam. Negara hadir ditengah konflik yang terjadi dalam membangun kerukunan umat beragama, karena kerukunan intra agama merupakan bagian penting dari kerukunan nasional. Kerukunan umat beragama adalah keadaan hubungan sesama umat beragama yang dilandasi toleransi, saling pengertian, saling menghormati, menghargai kesetaraan dalam pengalaman ajaran agamanya dan kerjasama dalam kehidupan bermasyarakat, berbangsa dan bernegara di dalam Negara Kesatuan Republik Indonesia berdasarkan Pancasila dan Undang-undang Dasar Negara Republik Indonesia Tahun 1945. Oleh karena itu, kerukunan hidup antarumat beragama merupakan prakondisi yang harus diciptakan bagi pembangunan di Indonesia. ${ }^{3}$

Untuk menciptakan kerukunan dan harmoniasi intra dan ektra umat beragama di Indonesia, pemerintah membantuk badan yang mengangani persoalan keagamaan dan dan konflik social keagamaan seperti MUI, FKUB dan Kemanterian Agama bagian dari pemerintah yang menangani khusus keagamaan. Keberadaan sosok ulama di Indonesia sudah ada seiring dengan masuknya Islam ke Indonesia, hingga saat ini ulama pun tetap memiliki peranan yang besar. Peranan ulama secara garis besar merupakan sosok yang bisa menjawab dan memecahkan setiap masalah sosial keagamaan yang senantiasa timbul dan dihadapi masyarakat, selain itu ulama dikatakan pula sebagai penjaga moral dan bentengnya masyarakat, sehingga eksistensi dan peranan MUI di Indonesia sangat besar untuk menyelesaikan persoalan social keagamaan. ${ }^{4}$

Majelis Ulama Indonesia (MUI) sebagai wadah musyawarah para ulama, dan cendikiawan muslim dengan tujuan sebagai berikut: Pertama, untuk memberikan bimbingan dan tuntunan kepada umat Islam Indonesia dalam mewujudkan kehidupan beragama dan bermasyarakat yang di ridhoi Allah. Kedua, memberikan nasihat dan fatwa mengenai masalah keagamaan dan kemasyarakatan kepada pemerintah dan masyrakat. Ketiga, meningkatkan kegiatan bagi terwujudnya ukhwah Islamiyah dan kerukunan antar umat beragama dalam memantapkan persatuan dan kesatuan bangsa serta. Keempat, menjadi penghubung antara ulama dan umaro (pemerintah) dan penterjemah timbal balik antara umat dan pemerintah guna mensukseskan pembangunan nasional.

FKUB adalah forum yang dibentuk oleh masyarakat dan fasilitas oleh Pemerintah dalam rangka membangun, memelihara dan memberdayakan umat beragama untuk kerukunan dan kesejahteraan. FKUB adalah wadah yang merupakan tempat dimusyawarahkannya berbagai masalah keagamaan lokal dan dicarikan jalan keluarnya. FKUB ini akan bertugas

\footnotetext{
${ }^{2}$ Abdul Aziz dan Imam Tholkhah, Gerakan Islam Kontemporer di Indonesia (Jakarta: Pustaka Firdaus, 1996), 5 .

${ }^{3}$ Mukti Ali. Kehidupan Beragama Dalam Proses Pembangunan Bangsa (Bandung: Proyek Pembinaan Mental Agama, 1975), 42.

${ }^{4}$ MUI Pusat, Himpunan Fatwa MUI Sejak Tahun 1975 (Jakarta: Erlangga, 2011), 4.
} 
melakukan dialog dengan pemuka agama dan masyarakat, menampung dan menyalurkan aspirasi oramas keagamaan dan masyarakat dan melakukan sosialisasi peraturan perundangundangan dan kebijakan di bidang kagamaan yang berkaitan dengan kerukunan umat beragama dan pemberdayakan masyarakat.

Kementerian Agama dengan melakukan pemberdayaan forum kerukunan umat beragama, dan pendirian rumah ibadat, pemeliharaan kerukunan umat beragama di setiap kabupaten dan provinsi. peran Kemenag dalam rangka kerukunan hidup antar umat beragama sangatlah besar, dimana Kemenag berperan aktif dalam melaksanakan tugas pemerintah yakni pembangunan bidang agama dan bidang pendidikan yang mengacu pada upaya pencapaian tujuan Kementerian Agama yang mencakup yaitu, (1). Peningkatan kualitas pemahaman dan pengalaman ajaran agama; penyediaan penyuluh agama, festival keagamaan, pemberdayaan lembaga sosial keagamaan; (2). Peningkatan kualitas kerukunan umat beragama; penguatan aspek regulasi/kebijakan, kapasitas aktor-aktor kerukunan umat beragama, pemberdayaan forum kerukunan umat beragama (FKUB) dan institusi media, pengembangan dan penguatan kesadaran kerukunan umat beragama, pembinaan aliran keagamaan; (3). Meningkatkan pendidikan agama Islam, Kristen, Katolik, Hindu, Buddha, dan Khonghucu. Kebersamaan, keharmonisan dan kerukunan dalam intra atau ektra umat beragama di Indoensia untuk memajukan kesejahteraan masyarakat lahir dan batin adalah tetap menjadi komitmen dan fokus pembinaan Kementerian Agama.

Provinsi Jawa Timur, peristiwa konflik bertema Sunni-Syiah baik yang terjadi di Jember maupun Sampang ini sepertinya sebuah kelanjutan mata rantai dari peristiwa serupa yang terjadi di berbagai daerah di tahun-tahun sebelumnya. Sebut saja, mulai dari penyerangan sekelompok massa terhadap para pengikut IJABI yang terjadi di Desa Jambesari Kecamatan Jambesari Darussolah Kabupaten Bondowoso, pada tanggal 23 Desember 2006, insiden penyerangan pesantren YAPI yang berpaham Syiah oleh sekelompok orang yang mengatasnamakan laskar Aswaja ada tahun 2010-211 di Bangil Pasuruan dan keteganganketengan berskala kecil yang terjadi Malang. Kejadian ini sangat mengejutkan, dimana biasanya orang jawa yang terkenal tidak suka kekerasan, seakan ada hal yang memicu konflik Sunni-Syiah harus terjadi.

Kemenangan Revolusi Iran tahun 1979 telah menggagalkan politik-politik Barat yang sebelumnya menguasai kawasan negara Islam. Iran yang sebelumnya tunduk dan patuh terhadap AS, pasca revolusi, justru lebih banyak menampilkan sikap yang berseberangan dengan negeri "Paman Sam" itu. Karenanya, AS merasa berkepentingan untuk menjaga agar konflik Sunni-Syiah itu tetap ada di wilayah Timteng demi melanjutkan hegemoninya di kawasan tersebut. ${ }^{5}$

Dalam konteks ini, terjadinya banyak konflik keagamaan di Indonesia, khususnya di Jawa Timur, membina kerukunan dan memproteksi dini konflik yang akan terjadi menjadi sangat urgen. Membangun kerukunan antar umat beragama merupakan pilar kerukunan nasional adalah sesuatu yang dinamis, karena itu harus dipelihara terus dari waktu ke waktu. Kerukunan hidup antar umat beragama sendiri berarti keadaan hubungan sesama umat beragama yang dilandasi toleransi, saling pengertian, menghargai kesetaraan dalam

\footnotetext{
${ }^{5}$ Faisol Ramdhoni. Di Balik Merebaknya Konflik Sunni-Syiah di Jawa Timur. http://www.nu.or.id., diakses Sabtu, 14 September 2017.
} 
pengamalan ajaran agmanya dan kerja sama dalam kehidupan bermasyarakat, berbangsa, dan bernegara.

Harmoni kehidupan bersama secara damai (peacefull co-existence) atau kerukunan umat bisa terwujud dan bertahan di Indonesia? Seperti diungkapkan oleh Atho' Mudzhar tidak lain karena eksistensi dan dominannya madzhab dan aliran Islam Ahlus Sunnah Wal Jamaah yang biasa juga disebut sebagai Sunni atau Sunnah. ${ }^{6}$ Memang ada juga pengikut Syi;ah di tanah air, tetapi jumlahnya jauh dari signifikan untuk dapat mempengaruhi perjalanan historis dan arsitektur sosiologis Islam Indonesia. ${ }^{7}$

Kabupaten Jember, termasuk salah satu kabupaten di Jawa Timur yang cukup dinamis dalam konteks pertumbuhan dan perkembangan paham keagamaan. Tetapi, dalam rentang waktu lima tahun terakhir, dari tahun 2012-2017 telah terjadi beberapa kasus perselisihan paham keagamaan di wilayah Kabupaten Jember seperti kasus perselisihan paham keagamaan Paham Keagamaan Qadriyatul Qasimiyah di Kecamatan Wuluhan, Lembaga Dakwah Islam Indonesia (LDII) di Kecamatan Tanggul, Pesantren Robbany di kecamatan Sumbersari, Sholawat Wahidiyah, Syi'ah, dan Salafi di daerah ingkungan Gladak Pakem dan Gumukbago yang samapi hari ini belumselesai penanganan sengketa pendidirian lembaga.

Sedangkan Kabupaten Bondowoso, juga terjadi perselisihan paham keagamaan, antara lain Sunni-Syiah dan Sunni-Salafi. Pada tahun 2006 pada tahun 2006 di Desa Jambesari merupakan salah satu desa yang terletak di Kecamatan Jambesari golongan Syiah secara terang-terangan berkelompok dan menyampaikan keyakinan keSyiah-annya sehingga memicu amarah dari kaum Sunni, bahkan perselisihan ini nyaris memakan korban. Selain di Kecamatan Jambesari, di kabupaten bondowoso di daerah kampong Arab antara Syi'ah dan Sunni, karena paham keagamaan Syiah yang dianut IJABI Bondowoso menyebabkan masyarakat merasa terganggu dengan mencaci maki seahabat selain Ali RA, dan juga pelaksanaan Milad Fatimah yang juga samp[ai ada gerakan massa yang menolak pelaksanaan Milad Fatimah tersebut.

Kajian ini memfokuskan pada konflik perselisihan paham keagamaan intra agama, bukan pada ektra agama. Karena di Kabupaten Jember dan Kabupaten Bondowoso kejadian konflik yang banyak intra agama, bukan ektra agama Islam. Penelitian di Kabupaten Jember dan Kabupaten Bondowoso, ingin mengungkap dan menganalisis munculnya perselisihan dan upaya mencari solusi agar perselisihan paham keagamaan ini segera berakhir dan tidak berulang kembali terus dilakukan, sehingga yang diinginkan adalah damai berkelanjutan, bukan damai sesaat yang sewaktu-waktu bisa muncul kembali.

\section{Pola Bentuk Perselisihan Paham keagamaan di wilayah Kabupaten Jember dan Kabupaten Bondowoso}

Manusia hidup tidak lepas dari konflik, sehingga dapat dipastikan bahwa usia konflik seumur dengan peradaban manusia. Konflik terjadi karena adanya perbedaan, persinggungan

\footnotetext{
${ }^{6}$ M. Atho Mudzhar, Menjaga Aswaja dan Kerukunan Umat (Jakarta: Puslitbang Kehidupan Keagamaan, Badan Litbang dan Diklat Kementerian Agama RI, 2012), 2.

${ }^{7}$ Azra, Azyumardi, "Aswaja dan Ummatan Washatan: Landasan Kerukunan Umat", dalam M. Atho Mudzhar, 2012, Menjaga Aswaja dan Kerukunan Umat (Jakarta: Puslitbang Kehidupan Keagamaan, Badan Litbang dan Diklat Kementerian Agama RI), xii.
} 
dan pergerakan. ${ }^{8}$ Sistem nilai, budaya, keyakinan cenderung mengelompokkan masyarakat dalam sekat-sekat kelompok yang bersifat kompetitif dan dominatif daripada hubungan yang bersifat koperatif. Hubungan sosial yang bersifat dominatif pada akhirnya akan melahirkan hukum tradisional dan primitif yaitu siapa yang kuat itulah yang menang dan berkuasa serta dialah yang membuat hukum. ${ }^{9}$

Konflik antar pemeluk agama dalam masyarakat majemuk seringkali mengandung muatan kompleks dan tidak sekedar menyentuh dimensi keyakinan dari agama yang dipeluk. Tetapi juga terkait dengan kepentingan sosial, ekonomi, politik dan sebagainya. Konflik antar pemeluk agama semakin meluas, jika didukung oleh adanya kelompok konflik kepentingan. Konflik sosial terjadi antara dua kelompok atau lebih, yang terwujud dalam bentuk konflik fisik antara mereka yang tergolong sebagai anggota-anggota dari kelompok-kelompok yang berlawanan. Dalam konflik sosial, jatidiri dari orang perorang dalam konflik tersebut diganti oleh jatidiri golongan atau kelompok. Dengan kata lain, dalam konflik sosial, yang terjadi bukanlah konflik antara orang perorang dengan jati diri masing-masing, melainkan antara orang perorang yang mewakili jatidiri dari golongan atau kelompoknya. ${ }^{10}$

Pola perselisihan paham keagamaan sekalanya berbeda-beda ada yang bersifat lokal, nasional dan internasional. Pola lokal perselisihan terjadi hanya pada daerah tertentu saja sementara daerah lainya paham keagamaan ini tidak ada, misalnya Ajaran Qadriyatul Qasimiyah dan pesantren Robbany. Pola perselisihan paham Nasional terjadi hampir diberbagai daerah ditanah air terutama daerah padat penduduk muslim, artinya perselisihan paham tersebut hampir terjadi diberbagai daerah tanah air karena perselisihan muncul dari organisasi yang berskala Nasional seperti LDII yang sejak lama keberadaannya menuai kontroversi. Perselisihan ajaran Qadriyatul Qosimiyah ini terjadi karena pemahaman pendiri yang mengatakan dirinya seperti allah, ajaran ini hamper sama dengan ajaran wahdatul wujud di Indonesia.

Aliran sesat adalah sekelompok manusia atau organisasi yang terorganisir yang memiliki pemahaman atau aturan-aturan tertentu yang bertentangan dengan ajaran Islam; menyimpang dari Al-Qur'an dan Sunnah. Pengikut suatu aliran tertentu adalah orang-orang yang telah terdoktrin pikirannya, tidak suka dialog, serba dogmatis, antikritik, dan cenderung merasa paling benar. ${ }^{11}$ Penyebaran aliran atau paham yang sesat dan menyesatkan jika dibiarkan jelas-jelas akan mengancam keselamatan generasi umat Islam saat ini dan yang akan datang. Ditinjau dari aspek bahayanya, aliran-aliran dan paham yang sesat dan menyesatkan tersebut memiliki dampak yang cukup kompleks, antara lain menimbulkan keresahan bagi masyarakat muslim secara luas sehingga dikemudian hari akan menimbulkan konflik di masyarakat itu sendiri.

Menurut Arifin Assegaf ada lima faktor penyebab konflik. Pertama, eksklusivitas dari pemimpin agama dan penganutnya. Kedua, sikap tertutup dan saling curiga antar agama. Ketiga, keterkaitan yang berlebih-lebihan terhadap simbol agama. Keempat, agama yang adalah tujuan berubah menjadi alat, realitas menjadi sekedar kebijaksanaan. Kelima, kondisi

\footnotetext{
8 Ridwan, "Piagam Madinah dan Resolusi Konflik: Model Penataan Hubungan Antar Umat Beragama", HARMONI Jurnal Multikultural \& Multireligius, Vol. VIII, No. 30 (April-Juni 2009), 144.

${ }^{9}$ Diana Francis, Teori Dasar Transformasi Konflik Sosial (Yogyakarta: Quilis, 2005), 8.

${ }^{10}$ Parsudi Suparlan, Konflik Sosial dan Alternatif Pemecahannya (Journal Antropologi Indonesia, 1999), 59.

${ }^{11}$ Hartono Ahmad Jaiz, Aliran dan Paham Sesat di Indonesia (Jakarta: Pustaka Al Kautsar, 2010), 11.
} 
sosial, ekonomi dan politik. ${ }^{12}$ Sedangkan Menurut Said Agil Husain, ada dua faktor penyebab konflik antar umat beragama yaitu faktor internal dan eksternal. Adapun faktor internal seperti adanya kecenderungan pemahaman radikal ekstrim dan fundamentalis terhadap ajaran agama yang dianut. Sedangkan faktor eksternal yaitu adanya pihak-pihak yang membuat skenario agar masing-masing agama tersebut senantiasa terlibat konflik. ${ }^{13}$

Fenomena sosial-keagamaan dibeberapa wilayah Jawa Timur yang melibatkan Syi'ah versus sunni terjadi pada masyarakat yang cukup militan dan ini berkembang di daerah suku Madura, misalnya yang terjadi di Sampang berikut juga Bondowoso dan Daerah Jember bagian pesisir Pantai Selatan yang mayoritas Suku Madura. Pola perselisihan Internasional, Nasional yang berefek berat pada lokal karena diderah basis arus bawah terutama di derah yang didominasi oleh kultur Madura paham yang berkembang pesat adalah paham Ahlussunnah wal Jama'ah yang sejak lama dianut secara fanatis oleh masyarakat di pedesaan, hal yang wajar bila gesekan perselisihan di arus bawah cukup kuat. Apalagi kelompok syiah sering meneriaki sahabat-sahabat nabi seperti Sahabat Abu Bakar, Umar dan Usman dengan kata-kata yang tidak pantas dan memandang paham lain sebagai paham yang sudah sesat inilah yang dianggap oleh Said Agil Husain sebagai paham yang cenderung radikal ekstrim dan fundamentalis terhadap ajaran agama yang dianut.

Pola perselisihan paham keagamaan di wilayah Kabupaten Jember dan Kabupaten Bondowoso berkembang dari perselisihan-perselisihan tingkat lokal, Nasional dan Internasional. Perselisihan paham keagamaan yang terjadi dilokal Jember tidak terjadi Bondowoso, sementara perselisaham paham keagamaan Nasional dan Internasional terjadi didua daerah tersebut. Bondowoso dengan masyarakat mono etnis artinya di dominasi oleh Etnis Madura sedangkan di Jember Kulturnya lebih varian bahkan saat ini dianggap memiliki kultur pandalungan karena di huni oleh etnis Madura dan Jawa.

Pola perselisihan paham keagamaan lokal sering muncul di derah Jember sedangkan paham kegamaan Nasional dan Internasional terjadi di dua derah tersebut.Selain pola perselisihan paham keagamaan dapat diklasifikasi berdasarkan pola skala geografis (lokal, Nasional, Internasional) perselisihan paham kegamaan juga bisa diidentifikasi berdasarkan tingkat ajaran dan pemahaman keagamaan. Pada pola pemahaman rata-rata pemahaman kegamaan yang berkembang karena penafsiran yang berbeda dengan penafsiran kegamaan mainstream seperti Qodariyah Qasimiyah yang ajaran-ajarannya banyak menyimpang dengan ajaran mayoritas Umat Islam Indonesia terutama Masyoritas Muslim Jember, begitupula dengan Pesantren Robbany mengembangkan ajaran yang bertentangan dengan ajaran yang dianut penduduk mayoritas. Polemik yang sama juga karena ajaran LDII dan Wahidiyah serta Syiah yang sering mengolok-olok para sahabat Nabi.

Pola pereselihan keagamaan yang terjadi baik Di Jember dan Bondowoso yang disebabkan oleh paham atau penafsiran ajaran kegamaan yang terpola pada Individu, Pelibatan Tokoh, Pengarahan Massa, Orasi. Pola individu menjadi penyebab perselisihan keagamaan. Pola ini terjadi pada individu yang memiliki tafsiran yang berbeda dengan para ulama'muktabarah sedangkan mayoritas masyarakat sudah terbiasa dengan ajaran ulama' Salaf dengan pada saat yang sama harus mendengarkan dan menerima ajaran baru yang masih

\footnotetext{
${ }^{12}$ Sumartana dkk, Pluralisme, Konflik dan Pendidikan Agama di Indonesia (Yogyakarta: DIAN/Interfidei 2005), 35 .

${ }^{13}$ Said Agil Husain Al Munawar, Fikih Hubungan Antar Agama (Jakarta: Ciputat Press, 2005), 21.
} 
belum jelas sanat keilmunnya pada Rasulullah. Individu ini menyasar ajaran-ajaran prinsip yang diyakini kuat oleh masyarakat misalnya Al-Quran dan Hadits. Penafsiran-penafsiran personal yang dikuti oleh sebagian masyarakat memicu terjadinya konflik pemahaman horizontal yang pada akhirnya dapat berubah menjadi konflik fisik. Individu baik yang mengajarkan dan pengamal menjadi masalah tersendiri di tengah-tengah masyarakat. Masyarakat Jember dan Bondowoso adalah masyarakat Santri mereka pengamal taat Ajaran Ulama-ulama' Sunni yang dikembangkan di berbagai Pesantren di Nusantara. Konflik Paham keagamaan dengan mudahnya terkuak dipermukaan karena santri atau simpatisan ini adalah santri yang responsif dan kritis, santri dan kyai hidup harmonis disudut-sudut kampung bahkan disetiap kampung ada para kyai dan santri pengamal ajaran setia Sunni, maka bila terjadi paham keagamaan yang berbeda dengan mudahnya riyak konflik itu cepat muncul.

Pola perselisihan kegamaan di Jember dan Bondowoso dari pola individu berkembang pada keterlibatan elit agama. Konflik Agama melibatkan konflik tokoh hal ini wajar karena tokoh-tokoh agama memiliki peran atau memiliki otoritas dibidang keagamaan untuk menafsirkan ajaran agama, sehingga para tokoh menjadi simpul-simpul dan patron dalam keberagamaan seseorang. Ajaran yang berkembang sudah sesat ditambah dengan konflik interest para tokoh menambah runyam perselisihan paham keagamaan tersebut.

Pelibatan tokoh dengan otoritasnya yang berbeda menjadi kunci dari penyebaran perselisihan kegamaan ditingkat dearah, karena bagaimanapun masing-masing tokoh memiliki Jama'ah lokal bahkan diluar daerah, jika para tokoh tersebut berkonflik maka efeknya juga pada para jama'ah, bila para tokoh level konfliknya hanya sebatas pada konflik penafsiran kegamaan namun ditingkat jamaah konflik ini bisa berubah pada konflik fisik seperti yang terjadi di Kecamatan Puger Tahun 2012. Pola konflik tokoh berakibat pada konflik keagamaan.

Pola Perselisihan kegamaaan di masing-masing daerah berbeda-beda, untuk pola Perselisihan kegamaaan yang terjadi di Kabupaten Jember dan Bondowoso terbagi pada pola Geografis, pola individu, keterlibatan tokoh, pengerahan Massa dan provokasi orasi. Polapola ini sangat berbahaya bila dibiarkan, konflik agama di India yang telah membelah Negeri Hindustan menjadi dua yaitu pakistan dan India. Negara harus hadir didepan mengatasi problem kegamaan tersebut. Perselisihan agama ditingkat lokal bukan berarti dengan mudah bisa diatasi oleh leading sector setempat, konflik lokal bisa merambah pada konflik berskala Nasional bila banyak konflik intrest masuk didaerah tersebut apalagi bila menyangkut persoalan kekuasaan dan aset-aset strategis ekonomi. Maka cara penanganan dari konflik ini harus melibatkan semua pihak secara terpadu dan sistemik.

\section{Mitigasi Konflik: Merekam Peran Stakeholder}

Peran organisasi keagamaan memiliki posisi sentral dalam menanggulangi konflik horizontal yang diakibatkan oleh konflik perbedaan paham keagamaan. Posisi peran strategis organisasi keagamaan dapat menjangkau lapisan akar persoalan yang dihadapi oleh masyarakat secara luas lebih-lebih yang berkaitan dengan doktrin agama. Persoalan keagamaan memang cukup berat diatasi, karena hal ini berkaitan dengan tingkat pemahaman seseorang terhadap teks-teks keagamaan, namun sepanjang organisasi yang konsen pada bidang tersebut berada didepan maka umat akan aman dari aliran-aliran sempalan dalam agama yang sering dimanfaatkan oleh seseorang dan kelompok tertentu. 
Adanya lembaga dan organisasi keagamaan seperti MUI, FKUB dan Kementerian Agama memiliki fungsi untuk membantu meredam konflik konflik bernuansa keagamaan yang terjadi di Kabupaten Jember dan kabupaten Bondowoso. Lembaga keagamaan berperan untuk meningkatkan pemahaman keagamaan. Dengan fungsinya sebagai penyalur kegiatan, pengembangan, dan pembinaan diyakini mampu membimbing anggota anggotanya untuk menumbuhkan kesadaran saling menghargai dan menghormati sehingga tercipta komunitas umat bergama yang rukun dan damai. ${ }^{14}$

Lembaga keagamaan memiliki fungsi manifest sebagai pedoman hidup masyarakat, sebagai sistem nilai yang mengatur hubungan antar masyarakat, sebagai pedoman keyakinan, dan tatanan kehidupan. Sedangkan fungsi laten dari lembaga agama adalah, agama sering dijadikan landasan untuk aktivitas SARA, sebagai kedok untuk meminta bantuan diluar kepentingan agama, dan seperti apa yang sedang kita alami saat ini yaitu memasukan agama dalam politik praktis dengan mengeluarkan ayat ayat Tuhan sebagai alat legitimasi untuk mewujudkan misi politik tertentu. Selanjutnya penulis akan menjelaskan secara detai tentang peran-peran isntitusi keagamaan MUI, FKUB dan Kementerian Agama sebagai berikut:

\section{Konstribusi Fatwa Majelis Ulama Indonesia (MUI)}

Posisi pertama yang berada digarda depan penanggulangan konflik keagamaan Jember dan Bondowoso adalah MUI. Sejak awal MUI dibeberapa konflik di Jember dan Bondowoso sudah banyak melakukan pembacaan pembacaan terhadap beberapa aliran yang berkembang baik yang berskala lokal, nasional dan internasional. Tentu hal ini cukup berarti bagi MUI Jember dan Bondwoso bila menghadapi aliran-aliran yang berskala internasional seperti sunni-syiah. Tetapi untuk kasus seperti aliran Qadriyatul Qasimiyah dan Pesantren Robbaniy di Jember tentu penanganannya cukup mudah karena berkembang ditingkat lokal.

Dari berbagai aliran-aliran yang berkembang, MUI Jember dan Bondowoso melalui komisi Fatwanya telah melakukan berbagai analisis-analisis yang tajam terhadap persoalan yang berkembang. Hasil kajian-kajian tersebut dijadikan pertimbangan untuk mengeluarkan sebuah fatwa. Disini peran MUI untuk memutus atau dan atau ikut memproteksi sebuah ajaran yang berkembang. Namun sepanjang beberapa kasus yang terjadi, Tugas MUI memberi fatwa dan Merekomendasi bahwa aliran-aliran yang berkembang sesat atau tidak. Untuk kasus Di Jember MUI memberi Fatwa sesat terhadap aliran-aliran yang telah dianggap menyimpang dan keluar dari ajaran arus utama. Fatwa MUI tersebut untuk memutus mata rantai sel ajaran yang sedang hidup sehingga publik paham dengab ajaran-ajaran tersebut haram diikuti oleh ummat. Peran MUI memberi kepastian terhadap umat akan bahaya ajaran-ajaran yang sesat tersebut terhadap keberlangsungan kerukunan umat ditengah-tengah masyarakat. MUI Jember dan Bondowoso telah memerankan institusinya sebagai anti bodi kerukunan umat beragama.

\section{Peran Sosio-Antropologis Forum Komunikasi Umat beragama (FKUB)}

Selain MUI Jember dan Bondowoso yang tidak kalah pentingnya adalah FKUB, meski FKUB organisasi kerukunan umat beragama yang berperan besar dalam menjaga

\footnotetext{
${ }^{14}$ Idrus Ruslan. Reorientasi Fungsi Lembaga Lembaga Keagamaan dalam Meningkatkan Perilaku Umat
} Beragama, (Lampung:Institusi Agama Islam Negri Raden Intan Lampung, 2014), 45. 
kerukunan antar umat beragama, tetapi pada kasus-kasus tertentu di Jember dan Bondowoso, kiprah FKUB cukup besar dalam menanggulangi ajaran-ajaran yang menyimpang. Peran FKUB sebagai mediator bagi kelompok-kelompok yang bertikai FKUB memediasi berupa dialog-dialog untuk mencari titik tetemu persoalan yang sedang terjadi. Langkah FKUB adalah salah satu solusi untuk mengurangi ketegangan-ketegangan yang terjadi. FKUB berusaha bersikap netral karena bukan ranahnya dalam perselisihan paham, tetapi langkah-langkah yang dilakukan FKUB salah satu solusi dalam menjembatani paham keagamaan yang sedang menjadi incaran bahkan amuk massa.

Pemerintah berusaha menjaga kerukunan umat beragama dengan menerbitkan Peraturan Bersama Menteri Agama dan Menteri Dalam Negeri Nomor 9 dan 8 tahun 2006 tentang Pedoman Pelaksanaan Tugas Kepala Daerah/Wakil Kepala Daerah dalam Pemeliharaan Kerukunan Umat Beragama Pemberdayaan Forum Kerukunan Umat Beragama, dan Pendirian Rumah Ibadah. ${ }^{15}$ Peraturan tersebut merupakan kebijakan penting dalam mewujudkan kerukunan umat beragama. ${ }^{16}$

FKUB Jember dan Bondowoso banyak terlibat aktif dalam proses penyelesaian kasus-kasus yang melibatkan kelompok masyarat. Kehadiran FKUB dapat membantu tugas-tugas instansi lain yang berwenang dalam hal ini yaitu MUI dan Kemenag. FKUB Jember dan Bondowoso telah berperan aktif dalam proses penyelesaian konflik keagamaan, hanya saja peran yang dimilikinya terbatas pada dialog-dialog terbuka untuk menjembatani perselisihan paham tersebut.

FKUB Kabupaten Jember dan Kabupaten Bondowoso berusaha mencegah terjadinya konflik bernuansa agama sedini mungkin agar kehidupan masyarakat kota Magelang khususnya dalam bidang keagamaan dapat tercipta sebuah keharmonisan. Cara yang dilakukan adalah dengan menuangkan konsep peace education ke dalam sebuah pendidikan non-formal yaitu dengan mengadakan kegiatan diskusi lintas agama bagi para pemuda. FKUB memiliki suatu pandangan bahwa dalam melakukan kegiatan peace education tidak harus menunggu terjadinya konflik, akan tetapi dapat diterapkan ke dalam masyarakat yang tidak terjadi konflik pencegahan sedini mungkin terhadap potensi munculnya konflik.

\section{Peran Konstitusional-Yuridis Kementerian Agama (Kemenag)}

Instansi lain yang juga berperan besar dalam konflik paham Keagamaan di Jember dan. Bondowoso adalah Kemenag. Disini langkah strategis Kemenag Jember dan Bondowoso melalui langkah-langkah proteksi dini. Proteksi dilakukan oleh lembaga dibawah naungan Kemenag yaitu PENMA, melalui kebijakannya PENMA menginstruksikan kepada seluruh pengawas untuk melakukan pembinaan sekolah pada tingkat guru baik pada Wilayah kerja MGMP maupun KKG dan peserta didik. Pembinaanpembina itu baik berupa seminar dan workshop yang relevan dengan ajaran agama. Hal ini

\footnotetext{
${ }^{15}$ Peraturan Bersama Menteri tersebut sering disebut dengan PBM. PBM merupakan pedoman bagi Kepala daerah/Wakil Kepala daerah dalam pemeliharaan kerukunan umat beragama. Peraturan ini menegaskan bahwa kerukunan umat beragama juga merupakan kewajiban pemerintah daerah karena kerukunan umat beragama merupakan bagian dari kerukunan nasional yang menurut Undang-undang Nomor 32 tahun 2004 pasal 22.

${ }^{16}$ Kustini, Peranan Forum Kerukunan Umat Beragama dalam Pelaksanaan pasal 8.9. 10 Peraturan Bersama Menteri Agama dan Menteri Dalam Negeri Nomor 9 dan 8 tahun 2006 (Jakarta: Maloho Abadi Jaya Press, 2010), 10.
} 
sebagai langkah para pengawas untuk membentengi para guru dari virus aliran-aliran yg sesat bahkan Radikalisme. Tidak hanya cukup disini Kemenag Jember juga melakukan control secara berkelanjutan baik pada generasi muda maupun tua melalui penyuluh agama yang berada di desa-desa, selain bertugas untuk memberikan pengayoman dan pendampingan keagamaan yang kuat pada umat, tugas menyuluh agama juga sebagai control terhadap aktivitas keagamaan masyarakat. Penyuluh agama yang berada digarda depan untuk memberikan informasi informasi yang sehat terhadap diri umat meski daya jangkaunya masih belum secara total mengcover seluruh lapisan masyarakat.

Proteksi dini Kemenag Jember melalui tangan PENMA dan penyuluh cukup ampuh untuk membentengi para generasi muda dan sekaligus generasi tua sekalipun. Kehadiran pengawas di lembaga-lembaga pendidik untuk terus mengkampanyekan ajaran-ajaran Rahmal lil alamin, begitu pula dengan para penyuluh selaku konsultan keagamaan pada tingkat masyarakat dilapisan bawah. dua kekuatan kementerian agama Jember diberi porsi pada lokusnya masing-masing. Untuk PENMA arah geraknya pada tingkat sekolah atau madrasah melalui penguatan guru-guru dan peserta didik, sementara penyuluh agama memperkuat basis pada generasi muda maupun tua ditengah-tengah masyarakat baik melalui dialog langsung maupun majlis ta'lim.

Pendekatan institusional sudah dilakukan oleh Kemenag Jember dengan berbagai pola baik melalui pola proteksi dini, pembinaan dan pengendalian. Sementara Kemenag Bondowoso terus melakukan pendekatan-pendekatan pada tokoh-tokoh agama setempat. Intensitas persuasif pada tokoh-tokoh Kabupaten Bondowoso, dipilih Kemenag agar dapat mendengar secara langsung problem krusial yang dihadapi oleh umat. Dengan intensitas komunikasi personal tersebut Kemenag Bondowoso dapat meminimalisir ruang Gerak konflik syiah yang ada dikabupaten Bondowoso,sehingga konflik tidak mudah menyebar luar luas. Pendekatan personal pada tokoh juga ampuh untuk membendung gelombang konflik yang lebih besar lagi, dan ini bisa dilakukan oleh Kemenag Bondowoso mengingat tempat atau lokasi terdampak konflik sudah di petakan sehingga tokoh-tokoh berpengaruh dengan kondisi daerah yang tidak begitu luas dengan mudah bisa dijangkau apalagi syiah di Bondowoso berkembang dan diajarkan oleh masyarakat keturunan Arab tepatnya dikampung Arab.

Dalam konteks membangun kerukunan umat beragama, untuk mewujudkannya dibutuhkan sebuah usaha yang sinergi dari berbagai pihak. Kerukunan umat beragama adalah keadaan yang membutuhkan kebersamaan dalam merealisasikan baik yang dilakukan oleh pemerintah melalui MUI, FKUB dan Kementerian Agama hingga masyarakat. Sebab, kerukunan merupakan kebutuhan semua pihak dan juga hal yang dibutuhkan. ${ }^{17}$

Hal terpenting yang harus dilaksanakan oleh MUI, FKUB dan Kementerian Agama Kabupaten Jember dan Kabupaten Bondowoso dalam rangka menciptakan perdamaian, kasih sayang, toleransi, saling pengertian, dan kerukunan hidup beragama adalah dengan cara membangun komunikasi antar umat beragama yang humanis dan dialogis. Komunikasi antar umat beragama merupakan media pembelajaran dan pendidikan dalam rangka menciptakan perdamaian. Dengan kata lain melakukan proses pendidikan

\footnotetext{
${ }^{17}$ Haidlor Ali Ahmad, Dinamika Kehidupan Keagamaan di Era Reformasi (Jakarta: Jaya Abid Press, 2010), 3.
} 
perdamaian (peace education). Sehingga kerukunan hidup antar umat beragama dapat terwujudkan.

\section{Tawaran Alternatif Solusi perselisihan Paham Keagamaan}

Rafael Raga Maran dalam Pengantar Sosiologi Politik menjelaskan bahwa integrasi sosial hanya akan terwujud bila individu- individu yang ada dalam suatu masyarakat menjauhkan diri dari prasangka dan diskriminasi. Dengan demikian konflik-konflik yang mengancam eksistensi masyarakat yang bersangkutan dapat dihindari. ${ }^{18}$

Dalam konteks penyelesaian konflik yang melanda masyarakat, fasilitasi dilakukan oleh tenaga khusus yang bertugas dengan beberapa cara. Pertama membina kelompok masyarakat yang terkena konflik sehingga menjadi suatu kebersamaan tujuan dan kegiatan yang berorientasi pada upaya perbaikan kehidupan.Kedua sebagai pemandu atau fasilitator, penghubung dan penggerak dalam pembentukan kelompok dan pembimbing pengembangan kegiatan kelompok. ${ }^{19}$

Menurut Dahrendorf ada tiga macam bentuk pengendalian konflik, yakni: a) Konsiliasi, yaitu pengendalian konflik yang dilakukan dengan melalui lembaga-lembaga tertentu yang memungkinkan diskusi dan pengambilan keputusan yang adil di antara pihak-pihak bertikai, dalam hal ini aliran-aliran keagamaan yang konflik melakukan diskusi melalui lembaga keagamaan seperti MUI, FKUB dan Kemenag, b) Mediasi, yaitu pengendalian yang dilakukan apabila kedua pihak yang berkonflik sepakat untuk menunjuk pihak ketiga sebagai mediator, dalam penyelesaian konflik keagamaan di Kabupaten Jember dan Kabupaten Bondowoso perlu ada pihak ketiga dalam hal ini seperti Polres dan Bakesbangpol sebagai lembaga pemerintah yang bertugas untuk memidiasi dan memfasilitasi terbentuknya perdamaian dari pihak-pihak yang konflik, c) Arbritasi, yaitu pengendalian yang dilakukan apabila kedua belah pihak yang berkonflik sepakat untuk menerima atau terpaksa menerima hadirnya pihak ketiga yang akan memberikan keputusan-keputusan tertentu untuk menyelesaikan konflik. Ketiga mekanisme pengendalian konflik ini banyak digunakan oleh pihak-pihak yang berkepentingan untuk menyelesaikan berbagai konflik sosial yang berlaku.

Ada beberapa solusi dan langkah strategis yang harus dilakukan oleh Majelis Ulama Indonesia (MUI), Forum Komunikasi Umat Bergama (FKUB), Kementerian Agama (KEMENAG) dalam menyelesaikan konflik paham kegamaan di Kabupten Jember dan Kabupaten Bondowoso sebagai berikut:

1. Sikap Tegas Pemerintah terhadap Aliran-aliran Keagama yang Menimpang

Pemerintah berkawajiban untuk menindak tegas bahkan melarang seluruh aktivitas aliran keagamaan yang dianggap sudah menyimpang. Solusi ini tidak Hanya sebatas pelarangan penyebaran paham namun perlu diikuti oleh tindakan yang tegas agar yang bersangkutan tidak mau lagi mengulanginya. Aktivitas keagamaan yang menyimpang jangan diberi angin segar oleh pemerintah karena bila pemerintah masih memberi ruang pada paham keagamaan yang sudah divonis sesat oleh MUI maka semua pihak tidak dibenarkan melindungi ajaran tersebut tanpa alasan apapun.

2. Partispasi Masyarakat Dalam Mencegah Munculnya Aliran yang Menyimpang

\footnotetext{
${ }^{18}$ Rafael Raga Maran, Pengantar Sosiologi Politik (Jakarta: Rineka C ipta: 2001), 184-185.

${ }^{19}$ Mansur Hidayat, Managemen dan Resolusi Konflik (Bandar Lampung: Fakultas Dakwah IAIN Raden Intan Lampung, 2013), 113.
} 
Sikap pro aktif masyarakat untuk terus mengawasi setiap gerak gerik penyebaran ajaran yang disebarkan oleh aliran-aliran keagamaan di Kabupaten Jember dan kabuoaten Bondowoso yang dianggpa menyimpang. Keterlibatan masyarakat dalam membatasi atau mencegah menyebarnya ajaran adalah langkah strategis. Karena masyarakatlah yang berada diujung depan yang berhadapan langsung dengan aliran menyimpang, dengan demikian masyarat harus pro aktif dengan instansi instansi yang berwenang untuk tetap makukan koordinasi.

Solusi persoalan LDII diantaranya pertama pihak LDII Pro aktif mendekati tokoh organisasi keagamaan lain, LDII harus bersikap melunak dan mau belajar terhadap tokohtokoh organisasi keagamaan lain. Bagaimanapun LDII harus bersikap inkulusif terhadap kelompok lain. Dari namanya saja LDII sebagai lembaga dakwah, maka sikap multi kultural harus lebih mengemuka pada semua lapisan masyarakat. Selain sikap inklusif terhadap kelompok keagamaan yang lain, LDII juga harus Memberi ruang pada tokoh lain untuk bisa melalukan aktualisasi dan impovisasi di LDII, dengan demikian maka LDII akan diterima oleh semua lapisan masyarakat dan solusi selanjutnya untuk LDII adalah melakukan pembinaan dengan cara memberikan bimbingan kepada seluruh pengurus dan Jama'ah. Pembinaan pada pengurus ini sangat penting baik berkaitan dengan manajemen dakwah, konten dan sasaran dakwah, sehingga tidak ada lagi masyarakat tersakiti,dirugikan oleh pihak LDII karena LDII sudah milik masyarakat secara umum.

Sikap inklusifitas LDII akan menambah energi umat dan masyarakat, sehingga kehadiran LDII tidak lagi menjadi pemicu keresahan ummat namun menjadi pencerah ummat tinggal bagaimana LDII menempatkan posisinya ditengah-tengah kominutas masyarakat secara bijak.LDII akan menjadi kekuatan Islam jika dapat merubah seluruh model dakwah yang selama ini dianggap miring oleh mayoritas masyarakat.

Selanjutnya untuk Pesantren Robbaniy solusi yang ditawarkan pertama, memperbaiki statategi dakwah, strategi dakwah adalah komponen penting dalam manajemen dakwah.disini statategi dakwah yang dianggap keluar dari garis yang telah di tentukan MUI agar senentiasa kembali ke jalan yang lurus, maka Pesantren Robbaniy akan mudah diterima oleh masyarakat luas. Selama ini masyarakat cukup sinsitif dengan perkembangan dakwah-dakwah yang menyeleweng karena Islam yang berkembang selama ini adalah Islam Ala-Ahlusunnah Waljama'ah dan terbukti memberi ketenangan,ketentraman dan keharmonisan pada seluruh lapisan masyarakat. Secara otimatis bila ada aliran yang dianggap menyimpang maka dengan cepat masyarakat disekitar itu akan mudah tersulut karena ajaran lama mereka sudah mengakar kuat, bahkan sudah mendarah daging, kedua, bagesbangpol, linmas,kemenag dan MUI punya data bese konflik. Data-data ini sangat penting untuk memetakan kekuatan dan kelemahan konflik serta potensi-potensi lain yang akan muncul.selama ini data-data konflik hanya berada di orotan kertas tampa ada databesasi konflik yang dapat digunakan untuk mengukur potensi konflik. Data-data ini dapat menjadi acuan semua pihak untuk dicarikan solusinya yang lebih pada solusi WinWin Solution.

Salusi Kasus Syiah selain solusi yang telah yang ada, maka semua instansi terkait diharapkan untuk melakukan pembinaan Kerukunan umat beragama secara berkelanjutan, kasus syiah memamang berbeda dengan kasus aliran yang lain. Kasus ini tidak hanya terjadi di daerah Bondowoso-Jember, namun disetiap tempat kasus sunni-syiah sering 
terjadi, faktornya berbeda-beda ada yang murni karena perselisihan paham sebagaimana konflik ajaran sunni-syiah, tetapi pecahnya konflik juga diawali oleh pengaruh tokoh dan kepentingan ekonomi serta politik dibalik itu, faktor ekonomi dan politik menjadi pemicu. Salah-satu solusi yang jitu tidak lain semua pihak terkait untuk terus melakukan pembinaan kerunan umat intern agama secara intens bahkan jika perlu volumenya harus ditingkatkan.

Untuk kasus Wahidiyah, solusi yang telah ada yaitu pemerintah dan pihak berwajib berkewajiban melarang dan mencegah ajaran tersebut karena sudah jelas menyeleweng berdasarkan fatwa MUI, dan solusi kedua yaitu Menarik beredarnya buku buku Pedoman Pokok-Pokok Ajaran Wahidiyah dan buku Kuliah Wahidiyah Untuk Menjernihkan Hati dan Ma'rifat Billah Wa Lirosulihi Saw.

3. Membentuk Desa Siaga Konflik

Desa siaga konflik, bukan berarti desa yang gemar dan didorong untuk konflik. Namun Desa siaga konflik adalah desa yang terdeteksi memiliki benih-benih konflik dan siap dirubah menjadi desa anti konflik, tentu desa ini harus dipolopori oleh para aktor-aktor dari pihak-pihak terkait baik dari unsur pemerintah, organisasi keagamaan dan organisasi swadaya masyarakat. Para aktor akan melakukan dekonstruksi berbagai pemahaman yang radikal dan intoleran, tentu para aktor tersebut akan terus mempromosikan Islam yang rahmatalillalamin.

4. Kerjasama Tim Terpadu Seluruh Instasi Pemerintah

Tim terpadu. Tim ini misalnya terdiri dari pemerintah (Pemda), MUI, FKUB, Kemenag dan organisasi kegamaan yang berperan melakukan waspada dini,proteksi dini dan penanggulangan konflik dan masih banyak peran-peran strategis lainnya, masingmasing lembaga memiliki daya yang berbeda dalam upayanya menghadapi konflik kegamaan. Namun sinergi tim tersebut untuk mempermudah koordinasi dan pembagian tugas dalam menjaga kondusifitas umat.

\section{Penutup}

Berdasarkan hasil kajian diatas, 1) Pola Perselisihan Paham keagamaan di wilayah Kabupaten Jember dan Kabupaten Bondowoso diantaranya, yaitu: a) Pola perselisihan paham keagamaan berskala lokal, Nasional dan Internasional. b) Pola keyakinan dan tafsirnya yang kontroversi terhadap teks keagamaan. c) Pelibatan tokoh dengan otoritasnya menyebabkan perselisihan kegamaan ditingkat dearah. d) Model tausiyah kegamaan yang kontroversial dan ujuran kebencian. 2) Peran institusi keagamaan MUI, FKUB dan Kementerian Agama dalam menangani perselisihan paham keagamaan di wilayah Kabupaten Jember dan Kabupaten Bondowoso, yaitu: a) Memberi kepastian hukum terhadap ajaran kelompok yang menyimpang dengan fatwa-fatwa yang mencerahkan. b) Organisasi keagamaan melakukan proteksi dini. c) Pembinaan-pembinaan hubungan umat beragama melalui instansi pemerintah dan lembaga swasta. 3) Solusi perselisihan paham keagamaan di wilayah Kabupaten Jember dan Kabupaten Bondowoso diantaranya, yaitu: a) Pemerintah berkawajiban untuk menindak tegas dan melarang aktivitas aliran yang dianggap menyimpang. b) Pro aktif masyarakat untuk mengawasi setiap gerak gerik penyebaran ajaran yang disebarkan oleh eks kelompok menyimpang. c) Paham-paham keagamaan bersikap inklusif dan moderat terhadap kelompok lain. d) Strategi dakwah yang berhaluan dakwah rahmatan lil alamin. e) Pembinaan secara 
continue pasca konflik. f) Membentuk desa siaga konflik. g) Terbentuknya Tim terpadu dari organisasi pemerintah dan non pemerintah.

\section{Daftar Rujukan}

Ahmad, Haidlor Ali. Dinamika Kehidupan Keagamaan di Era Reformasi, Jakarta: Jaya Abid Press, 2010.

Ali, Mukti. Kehidupan Beragama Dalam Proses Pembangunan Bangsa, Bandung: Proyek Pembinaan Mental Agama, 1975.

Effendi. Islam dan Dialog Budaya, Jakarta: Puspa Swara, 1994.

Francis, Diana. Teori Dasar Transformasi Konflik Sosial, Yogyakarta: Quilis, 2005.

Hidayat, Mansur. Managemen dan Resolusi Konflik, Bandar Lampung: Fakultas Dakwah IAIN Raden Intan Lampung, 2013.

Jaiz, Hartono Ahmad. Aliran dan Paham Sesat di Indonesia, Jakarta: Pustaka Al Kautsar, 2010 .

Kustini. Peranan Forum Kerukunan Umat Beragama dalam Pelaksanaan pasal 8.9. 10 Peraturan Bersama Menteri Agama dan Menteri Dalam Negeri Nomor 9 dan 8 tahun 2006, Jakarta: Maloho Abadi Jaya Press, 2010.

Maran, Rafael Raga. Pengantar Sosiologi Politik, Jakarta: Rineka Cipta, 2001.

Mudzhar, M. Atho. Menjaga Aswaja dan Kerukunan Umat, Jakarta: Puslitbang Kehidupan Keagamaan, Badan Litbang dan Diklat Kementerian Agama RI, 2012.

MUI Pusat. Himpunan Fatwa MUI Sejak Tahun 1975, Jakarta: Erlangga.

Munawar (al), Said Agil Husain. Fikih Hubungan Antar Agama, Jakarta: Ciputat Press, 2005.

Peraturan Bersama Menteri tersebut sering disebut dengan PBM. PBM merupakan pedoman bagi Kepala daerah/Wakil Kepala daerah dalam pemeliharaan kerukunan umat beragama. Undang-undang Nomor 32 tahun 2004 pasal 22.

Ramdhoni, Faisol. Di Balik Merebaknya Konflik Sunni-Syiah di Jawa Timur. http://www.nu.or.id Sabtu, 14 September 2013. Diaskase Tanggal 25 Oktober 2020.

Ridwan. "Piagam Madinah dan Resolusi Konflik: Model Penataan Hubungan Antar Umat Beragama", HARMONI Jurnal Multikultural \& Multireligius, Vol. VIII, No. 30 AprilJuni 2009.

Ruslan, Idrus. Reorientasi Fungsi Lembaga Lembaga Keagamaan dalam Meningkatkan Perilaku Umat Beragama, Lampung: Institusi Agama Islam Negeri Raden Intan Lampung, 2014.

Sumartana. Pluralisme, Konflik dan Pendidikan Agama di Indonesia, Yogyakarta: DIAN/Interfidei, 2005.

Suparlan, Parsudi. Konflik Sosial dan Alternatif Pemecahannya, Journal Antropologi Indonesia, 1999. 
Tholkhah, Abdul Aziz dan Imam. Gerakan Islam Kontemporer di Indonesia, Jakarta: Pustaka Firdaus, 1996. 